\title{
THE EXERCISE OF ICT IN ELT: A LITERATURE REVIEW
}

\author{
S Arafin \\ Postgraduate Student, Department of English, Uttara University, Dhaka, Bangladesh.
}

Article DOI: https://doi.org/10.36713/epra5170

\begin{abstract}
The integration of ICT in ELT impacted education in the broader sense that language instructors cannot remain stuck to just board-and-duster anymore. It has been mandatory for the teachers to blend digital content with existing materials. However, it has not been easy to employ authentic-digital materials due to some flaws in the education system (i.e., in developing countries like Bangladesh). In addition to that, the unavailability of technological equipment in most schools, together with teachers' insufficient practical expertise, is a bar to language teaching and learning. Regardless of the drawbacks in the application of ICT in ELT in practice, nothing better than technology is found to set up a positive learning environment for language learners.
\end{abstract}

KEYWORDS: ICT, ELT, Authenticity, Autonomy, Communication, Technology.

\section{INTRODUCTION}

Modern methods and approaches to teaching and learning a target language require the confirmation of authentic materials and authentic tasks. Autonomy, another vital aspect in ELT, is believed to be an influencing factor in learning. Authenticity, as well as the independence of the students, can be achieved by applying ICT. If technologically skilled teachers are well equipped with modern technologies, they can use different strategies through ICT-based tools to motivate the learners. But the problems arise when the exercise of ICT in ELT is considered a fancy way of teaching and learning. In most cases, especially in rural zones, language instructors show disinterest in ICT and advocate for traditional methods such as the GrammarTranslation Method (GTM). To promote the integration of ICT with ELT, both the government and the experts should take steps to train the teachers for developing their ICT-related skills and positive attitude towards its application.

\section{LITERATURE REVIEW}

Modern technology has introduced techniques that can assist in preparing materials and tasks fast. Rank, Warren, and Millum (2011) believe that teachers can effortlessly explore, investigate and analyse to identify good quality content for the learners. They continued saying that ICT can also encourage and engage the students in participating in communicative tasks through entertainment. Interestingly, besides giving easy and fast access to education, technology is curtailing the cost of schooling. (Bax 2000, 199). However, Bax did not suggest replacing the whole system with a technology-based platform; instead, he emphasised accepting technology as a partial solution to pedagogic issues. (Bax 2000, 200).

While mentioning the achievements of ICT in ELT, Ghasemi and Hashemi (2011) expressed that it widens educators' scopes to monitor and assess students' progress and excels students' language skills required for academic and communicative platforms. In today's world, it is even possible to connect the learners with the target language culture as ICT provides the opportunity to have real interaction with 


\section{SJIF Impact Factor: 7.001| ISI I.F.Value:1.241| Journal DOI: 10.36713/epra2016 ISSN: 2455-7838(Online) EPRA International Journal of Research and Development (IJRD)

the native speakers of English. They furthered stated that a strong correlation exists between the percentage of application of ICT and the improvement rate of learning.

It has been a significant research subject: whether ICT can boost autonomous learning and confirm authentic materials, contextualizing real-life situations. (Otero R. G. 2016). Otero (2016) found that students' language skills' remarkable progress was noticeable after using ICT-based authentic materials. Azmi (2017) also concluded that ICT successfully introduces materials that provide the students with original language and engage them with the tasks that promote autonomy.

Nevertheless, it appears likely that it is challenging for some teachers to exercise ICT in an ELT environment; therefore, the success entirely depends on how skilled the teachers are. (Hashemi 2016, 208). Many researchers came up with the idea that training the teachers in ICT is a requisite for integrating technology with ELT. Samuel and Zaitun (2007) proposed that training should be a continuous process to cope with the changing needs and updates. An instructor's positive attitude and confidence will improve if $\mathrm{s} / \mathrm{he}$ pursues a 'teaching-practicum' course (for a specific subject/course) that involves integrating ICT in the classroom. (Latchem 2010). But teachers' training projects are less likely to be successful unless the government and educational institutions offer adequate investment and proper support. (Jung 2005).

A study conducted by the Bangladesh Bureau of Educational Information and Statistics (BANBEIS) in 2015 presented that both the Ministry of Education and the Ministry of ICT provided the teachers with training. However, the number of teachers who received training is not significant. Further, it was recommended that government should supply advanced electronic devices at the best prices to the educational institutions

\section{CONCLUSION}

To conclude, it can be said that ICT will not work its usual magic to help in teaching and learning English unless the educators receive adequate training in ICT. Once the language instructors are equipped with theoretical knowledge of ICT and technical skills, they will be able to pave smooth ways for their pupils. Because ICT can establish multiple mediums of communications and build a bridge between the learners and the target language culture and society, it would not be a perfect choice to ignore the adoption of technology into ELT.

\section{REFERENCES}

1. Azmi, N. (2017). "The Benefits of Using ICT in the EFL Classroom: From Perceived Utility to Potential Challenges." Journal of Educational and Social Research, 7 (1), 111-118, Doi:10.5901/jesr.2017.v7n1p111

2. Bax, S. "Putting Technology in its Place: ICT in Modern Foreign Language Teaching. ” In Field, K. (ed.), Issues in Modern Foreign Language Teaching. RoutledgeFalmer: Taylor \& Francis.

3. Ghasemi, B. and Hashemi, M. (2011). "ICT: New Wave in English Language Learning/Teaching." Procedia Social and Behavioral Sciences, 15 (2011) 3098-3102

4. Hashemi, A. (2016). "The Impact of Information and Communication Technology (ICT) on Teaching English to College Students." EFL Journal, 1 (3), 203-218.

Doi: http://dx.doi.org/10.21462/eflj.vli3.20

5. "Impact and Status of ICT Training for School Teacher." By Bangladesh Bureau of Educational Information and Statistics (BANBEIS). Retrieved from

https://banbeis.portal.gov.bd/sites/default/files/files/ banbeis.portal.gov.bd/page/bf60bc17_7f35_45aa_a 082_8aedd460dd8a/2015_Impact\%20and\%20Statu s\%20of\%20ICT\%20Training\%20for\%20School\%2 oTeacher.pdf

6. Jung, I. (2005). "Ict-Pedagogy Integration in Teacher Training: Application Cases Worldwide." Educational Technology \& Society, 8 (2), 94-101

7. Latchem, C, (2010). "Using ICT to Train Teachers in ICT." In Danaher, P.A and Umar, A. (eds.) Teacher Education through Open and Distance Learning. 75-93. Commonwealth of Learning

8. Otero, G. R. (2016). "Innovative resources based on ICTs and authentic materials to improve EFL students' communicative needs". In A. ParejaLora, C. Calle-Martínez, \& P. Rodríguez-Arancón (Eds), New perspectives on teaching and working with languages in the digital era (pp. 83-93). Dublin: Research-publishing.net. http://dx.doi.org/10.14705/rpnet.2016.tislid2014.42 4

9. Rank, T., Warren, C., and Millum, T. (2011). "Teaching English Using ICT: A Practical Guide for Secondary School Teachers." Continuum Internaitonal Publishing Group

10. Samuel, R.J. and Zaitun, A.B. (2007). "Do Teachers Have Adequate ICT Resources and the Right ICT Skills in Integrating ICT Tools in the Teaching and Learning of English Language in Malaysian Schools?" The Electronic Journal on Information Systems in Developing Countries, 29 (2), $1-15$ 